\title{
The Environment And Textbooks: Are They Enabling Sustainable Outcomes?
}

Nick Barter: n.barter@griffith.edu.au *+61 7373 53250* Griffith University, Brisbane, Australia

Abstract: A central claim within the sustainable development literature is that realizing sustainable outcomes requires a move away from a conceptualization of the environment as a separate, bounded, independently given entity. In this paper, the conceptualization of the environment within bestselling strategy textbooks in the UK and Australia in 2011 is reviewed. A focus on strategy textbooks is taken as it is argued that corporate strategists are key actors in the realization of sustainable outcomes. Thus the constructs those individuals may learn from texts are potentially key to their ability to realize sustainable outcomes. The findings show that the constructs in the textbooks offer a sclerotic, dehumanized view of the environment that is partitioned into external and internal categories by an organizational boundary. Thus if strategy textbooks are tools to help corporate strategists learn strategy, who will then enable sustainable development, changes are required.

$\underline{\text { Keywords: }}$ strategy textbooks; sustainable development; monistic versus dualistic

"It is quite simple wrong to regard action on the psyche, the socius, and the environment as separate... [to present these areas as if they are separate is]... acquiescing to a general infantilisation of opinion" (Guattari, 1989: 134).

\section{INTRODUCTION}

All narratives are an outcome of an inevitable refraction by their author(s) and knowingly or unknowingly, all have had in the process of their writing a "rhetorical razor ... [applied] that defines included and excluded, relevant and irrelevant, empowered and disempowered" (Cronon, 1992: 1349). Indeed this article, suffers the same fate. Textbooks are not necessarily conceived as suffering with refraction or rhetorical razors. For example, the metaphor of 'textbook operation' implies operating to a set of agreed upon and regulated procedures (Crawford, 2003), procedures that imply operations are conducted in a bubble of ahistorical, decontextualized truth (Cummings \& Bridgman, 2011). Consequently, as Apple and Christian-Smith (1991) argue textbooks are commonly conceived as a "delivery system of facts" (p. 1). Wherein they are infused with a "foundational epistemological assumption-that they have a status, a bona fide status with a potential for universal application" (Issitt, 2004: 685). This aspect of textbooks necessarily drags with it criticisms of them being ideological devices that capture claims to truth and through their application in education help to legitimize a particular social order, while normalizing students into that same order (e.g., Bouvier, 1984; Cameron et al., 2003; Crawford, 2003; Gilbert, 2003; Issitt, 2004; Mir, 2003; Pingel, 1999). Not least because textbooks are socially constructed devices that suffer the consequences of not only an author's refraction and rhetorical razor but also the compromises that arise from negotiations with numerous actors for example; publishers, editors and focus groups, in order to realize a finished, published product (e.g., Cameron et al., 2003; Ferguson et al., 2006; Mir, 2003).

Notwithstanding that textbooks may not be read at all by students (Apple \& Christian-Smith, 1991; Cameron et al., 2003), ripostes to the criticisms of textbooks as normalization devices are 
that any text can have multiple readings (Crawford, 2003) and that the text may not necessarily reflect what is taught in a classroom (Apple \& Christian-Smith, 1991; Cameron et al. 2003; Enz, 1986; Hackley, 2003). For example a reader of a textbook may not end up being paradigmatically colonized by the text and an instructor may use a textbook purely as a foil from which to develop deconstructive and critical arguments regarding the 'facts' within. Nevertheless the central challenge that textbooks are ideological devices that can normalize students into a particular social order, and in so doing a particular pattern of conceptualization remains (e.g., Ross \& Murdick, 1977; Cummings \& Bridgman, 2011; Bouvier, 1984; Enz, 1986; Mir, 2003).

This paper reviews some of the content of the best selling strategy textbooks in the United Kingdom and Australia. At the time of conducting the study attempts were made to obtain a list of the best selling strategy books in the United States of America, however that data proved unobtainable. The review of the textbooks is focused on how the environment is conceptualized, albeit the data presented is not limited to this alone. This study of how bestselling strategy textbooks conceptualize the environment was conducted because of arguments within the sustainable development literature. To précis those arguments, the sustainable development literature argues for a move away from a fractured epistemology that separates out the environment as being a separate entity to humans and in turn organizations (e.g., Egri \& Pinfield, 1999; Gladwin et al., 1995; Shrivastava, 1995). In so doing it argues for a move away from a Cartesian dualism, to the embrace of systemic, non-bounded understandings of humanity's relationship with all that surrounds us. Thus the sustainable development literature is arguing that humanity's conception of the environment should not be that the environment is a separate, bracketed out thing. The relevance of this to strategy textbooks is that the United Nations, notwithstanding others, argues that key protagonists in the realization of sustainable outcomes are organizations and in turn "corporate strategists" (UNSGHLPS, 2012: 22). Consequently, if corporate strategists are key actors in the realization of sustainable outcomes it is appropriate to question how the environment is conceptualized within the textbooks those strategists may use.

The paper proceeds in the following manner. First a discussion of sustainable development, its identification of organizations and corporate strategists as key actors and its challenge to separable, bounded understandings of the environment is brought forward. The study's design, methodology and mode of data collection are then discussed. Following this the findings are presented. To close, the implications of the findings are discussed.

To end this introduction, it should be noted, as was alluded to earlier, this paper is caught within its own web; it is a refraction, and it has had a rhetorical razor applied. Thus it should be recognized that the power of this paper may not be what it proves, but rather what it suggests (Fiol, 1989).

\section{SUSTAINABLE DEVELOPMENT KEY ACTORS AND CONCEPTIONS OF THE ENVIRONMENT}

The challenge of environmental and social degradation initiated a call for sustainable development. The roots of the contemporary call for sustainable development can be found, arguably, within the publication of Silent Spring (Carson, 1962) and the environmental movement of the 1960s, with sustainable development entering the mainstream consciousness via Our 
Common Future (WCED, 1987), the 1987 United Nations publication (Shrivastava \& Hart, 1994; Steer \& Wade-Gery, 1993; Yates, 2012) that defined sustainable development as "development which meets the needs of the present without compromising the ability of future generations to meet their own needs" (WCED, 1987: 8). Although this definition can suffer critiques (e.g., Banerjee, 2003), it is generally accepted that sustainable development is an idea increasingly important for organizations and business leaders to embrace (e.g., Blewitt, 2008; Brych et al., 2007; Gladwin et al., 1995). Especially as we "live in an organizational world in which organizations are the means through which interests are realized" (Egri \& Pinfield, 1999: 225), and as such enabling sustainable outcomes requires "organizations in general and business in particular" (Gray et al., 1993: 9).

If organisations are central actors, then organisational leaders and corporate strategists are also key, especially as these individuals are critical in marshalling the resources of and setting the direction of organisations. In the United Nations 2012 update to Our Common Future (1987), Resilient People, Resilient Planet (2012), “corporate strategists" (UNSGHLPS, 2012: 22) are identified as key actors who "have more opportunity than ever to pick and choose from the best practices and resources ... combine them in new and previously unforeseen ways ... [and thus help] to drive sustainable development" (UNSGHLPS, 2012: 22). While corporate strategists are key actors in the realization of sustainable outcomes through their influence upon the strategy of organizations, key to the enablement of sustainable outcomes is their cognition, especially if it is accepted that individuals act upon the basis of their cognitive representations of the world around them, their environment (e.g., March \& Simon, 1958; Simon, 1947; Lakoff, 2010).

With regard to our conceptualization of the environment, most simply and directly Our Common Future (also referred to as the Brundtland Report) argues, "[T] he environment does not exist as a sphere separate from human actions, ambitions, and needs, and attempts to defend it in isolation from human concerns have given the very word environment a connotation of naivety" (WCED, 1987: xi). This statement directly implicates a move away from a conception of the environment as being something that is a thing that is bounded, separate and external to humanity. It implies a movement towards a monistic and away from a dualistic understanding of humanity's relationship with the planet.

To build the case Our Common Future (1987) argues that humans have historically understood the planet as "a large world in which human activities and their effects were neatly compartmentalized within nations, within sectors (energy, agriculture, trade) and within broad areas of concern (environmental, economic, social)" (WCED 1987: 4). This historical understanding conceptualizes the world as consisting of separate domains for example, environment, society and economy. However, the challenge of this type of conceptualization is that ultimately it relies upon and reinforces a false dichotomy that there are two separate categories on the world: humans and everything else (nature). (For further explanation see Castree, 2002; Latour, 1999a, 1999b; Newton, 2002.) This is counter to the "real world of interlocked economic and ecological systems ... [that] will not change" (WCED, 1987: 9). Thus if the 'real' world will not change, the challenge is whether humanity's understandings and our "policies and institutions" (WCED, 1987: 9) can, lest sustainable outcomes are forfeited. 
As such the call for sustainable development is also a call for a change in humanity's understandings. Whereby to realize sustainable development humans need to embrace an understanding that the environment is not separate and out there, but rather it surrounds and is entwined with them (Ingold, 2011). Consequently, sustainable development is not about saving "the environment," because to do so implies that the environment is a separate thing. Rather, sustainable development is about humans (present and future) developing and facilitating their development through a change in humanity's understanding of itself relative to everything else. A change that moves away from dualistic to a monistic (i.e., singular, not split), noncompartmentalized (non-bounded) understanding. In this regard it could be argued we need to recognize the "mutual embedding of humans and the rest of nature" (Starik \& Kanashiro, 2013: 8). And while this mutual embedding may be "so obvious that many of us take this special connection for granted" (Starik \& Kanashiro, 2013: 8) the challenge is that "all human organizations are embedded within the natural environment, and that all of those which have human managers and other employees, also contain the natural environment inside of their respective biophysical bodies" (Starik \& Kanashiro, 2013: 9), and thus there is no separation.

The logic within the argument is that there is a misalignment between humanity's ontology (reality) and epistemology (knowledge practices) that needs rectification. In short, we are suffering with a "profound epistemological crisis" (Gladwin et al., 1995: 874), wherein we need to move to a knowledge base that implies a connectionist ontology as opposed to an atomistic ontology (Boisot \& McKelvey, 2010). In turn this requires changes to theories and frameworks so that they do not assume and or perpetuate the notion that there is a "phenomenal world [that can be] directly and unproblematically observed and described by a disinterested actor who remains external to what is being observed" (Boisot \& McKelvey, 2010: 415).

In particular given that organizations and corporate strategists are key actors in the realization of sustainable development, this ontological-epistemological misalignment is a challenge to organizational theory. Theories of organization typically put the organization as the central concern and perpetuate notions of their being a separate environment that is to be analyzed and exploited (e.g., Egri \& Pinfield, 1999; Shrivastava, 1995). While theories that separate may enable particular forms of analysis, they ultimately so not enable sustainable outcomes, as the separation is a naive understanding (WCED, 1987) that fails to recognize systemic interconnections. Thus, in order to realize sustainable outcomes, organizational theories need reorientation towards organizations not being considered as separate from their surroundings (e.g., Egri \& Pinfield, 1999; Katz \& Gartner, 1988; McAuley et al., 2007; Sarasvasthy, 2001, 2004).

Taken together, the logic of this paper is that organizations, and in turn corporate strategists, are key actors in the enabling of sustainable development, which will require a change in humanity's understandings such that humans do not see themselves as separate from all that surrounds them; i.e., separate from nature or the environment. Theories guide action, but theories that imply and perpetuate a world of separations will not guide sustainable action. Consequently, since organizational strategists learn the fundamentals of strategy in university strategy courses, many of which have associated textbooks, the definitions of the environment provided by those textbooks needs to embrace a monistic view. As the perpetuation of a dualistic understanding implies that the future organizational strategist may have a conceptualization that reinforces a 
separation between the organization and the environment and that thus hinders the individual's ability to enable organizations to realize sustainable outcomes.

\section{RESEARCH DESIGN, METHODOLOGY AND DATA COLLECTION}

The aim of this research was to investigate the conceptualization of the environment in strategy textbooks. simple search on the Amazon bookselling website confirms that there is a plethora of strategy textbooks on the market; identifying bestsellers was necessary to develop a manageable list. In order to obtain lists of best-selling textbooks, some of well-known publishers of academic textbooks (e.g., Wiley, Pearson, McGraw Hill and Cengage) were contacted in November 2011 for advice and current bestseller rankings for sales of strategy/strategic management textbooks in the territories of the UK, Australia and the United States of America.

In addition to the publishing houses, and as a way of triangulating the data obtained, Neilsen BookScan, the international book sales data monitoring company, was contacted for sales data on strategy textbooks within the aforementioned territories. As an additional way of triangulating the data, the University Co-operative Bookshop chain of Australia - the largest seller of textbooks and has a presence on virtually every Australian campus - was contacted for strategic management textbook sales in the year to October 2011 (the most recent 12 month period they could provide at the time of the request).

A variety of lists was obtained: a list of the twenty bestselling strategy textbooks in Australia in 2011, a separate list for the twenty bestselling strategy textbooks in the UK, a list of sales for strategy/strategic management textbooks for the year to October 2011 from the University CoOperative Bookshop in Australia, and two lists from publishers on their bestsellers. Collating these various lists resulted in a list of 46 strategic management textbooks. To create a shorter list of the bestselling textbooks in Australia and the United Kingdom the following decision rules were applied: A textbook would be included in the final shortlist if (1) it was ranked in the top ten of either an Australian or UK ranking according to a sales data monitoring organization, (2) it was in the top 20 of an Australian and UK ranking according to a sales data monitoring organization, (3) it was in the top ten of sales according to the University Co-Operative Bookshop of Australia, (4) it was included in the top ten of other lists that were provided on bestselling or course adopted textbooks by publishers. These decision rules resulted in a shorter list of 23 textbooks.

\section{RESULTS}

The author of this study reviewed each of the 23 textbooks shown in Table 1, identified the ways in which each defined or discussed internal and/or external environments, and identified the ways in which each addressed sustainability or sustainable development. The resulting table of analytical results has been excluded from this publication for the sake of brevity, but it is available from the author.

The conceptualization of the environment within the textbooks reveals a number of consistent messages. First there is lack of definitional exactitude regarding what the environment is, and/or there are multiple categories of environment discussed. Second the environment is consistently 
discussed as being a repository of opportunities and threats that an organization needs to analyze, exploit and avoid. Third an organization has an external and internal environment. Taking each point in turn, to illustrate the lack of definitional exactitude and multiplicity of categories, Carpenter and Sanders (2009) highlight that the "external environment consists of a wide array of economic and socio-political factors" (Carpenter \& Sanders, 2009: 106). Similarly Hanson et al (2011) outline that a "firm's external environment is divided into three main areas: the general, industry and competitor environment" (Hanson et al., 2011: 36); wherein the general environment is "composed of dimensions in broader society that influence an industry and indirectly, the firms within it" (Hanson et al., 2011: 37). Likewise, Capon (2008) describes the external environment as "literally the big wide world in which organizations operate" (Capon, 2008: 31); while Hubbard and Beamish (2011) outline that "the environment represents all those aspects outside the organization that affect the business strategy of an organization" (Hubbard \& Beamish, 2011: 21). In the same way, Thompson and Martin (2010) define the environment as "everything and everyone outside the organization or organizational boundary-including competitors, customers, financiers, suppliers and government" (Thompson \& Martin, 2010: 787), and Wheelan and Hunger (2010) state, "[T] he external environment consists of variables (opportunities and threats) that are outside the organization" (Wheelan \& Hunger, 2010: 16). Thus the environment is a wide array of factors, general dimensions in society, variables, and categories. Reinforcing this lack of definitional exactitude, the environment is not only a general thing it is also described more specifically as "much more than the ecological green issues that word commonly evokes" (Capon, 2008: 31) and/or an element that has "long been a factor in firm strategy, primarily from the standpoint of access to raw materials" (Carpenter \& Sanders, 2009: 111).

With regard to the environment being a repository of opportunities and threats, the texts are consistent. The "external environment is where the opportunities and threats arise from to confront the organization" (Capon, 2008: 6). In addition "the environment is what gives organizations their means of survival. It creates opportunities and presents threats" (Johnson et al., 2011: 49). Further by analyzing the external environment "a firm identifies the critical threats and opportunities in its competitive environment" (Barney \& Hesterly, 2010: 8), especially as these threats and opportunities "could significantly benefit or harm an organization in the future" (David, 2011: 43). Crucially "identifying opportunities and threats is an important objective of studying the general environment" (Hitt et al., 2011: 39) if not the sole objective. For example, Grant (2010) highlights, "[T] he emphasis of the book has been the identification of profit opportunities in the external environment of the firm" (Grant 2010: 122). Given the texts are consistent in their view that "successful managers must recognize opportunities and threats" (Dess et al., 2010: 40) a focus on the environment being a repository of opportunities and threats is self-reinforcing. Especially because opportunities and threats affect how a firm "pursues its mission" (Hill \& Jones, 2010: 17) and "provide a foundation for strategic direction" (Harrison \& John, 2010: 4).

The third key construct offered by the majority of the textbooks (18 out of 23 ) is the concept that an organization has an internal and external environment. This construct is shown through the quotes above that alight upon the term external environment. In addition the notion of external and internal environments is reinforced through the position that key to strategic management is "environmental scanning (both external and internal)" (Wheelan \& Hunger, 2010: 
5) to, as indicated above, uncover opportunities and threats. Further the external environment constitutes "the forces that act outside of an organization" (Viljoen \& Dann, 2003: 451), and managers need to consider an organization's position "in the external environment" (Capon, 2008: 28) that is "surrounding" it (De Wit \& Meyer, 2010a: 110).

Table 1. Strategy Textbooks Reviewed in this Study

Angwin, D., Cummings, S., \& Smith, C. (2008). The strategy pathfinder: Core concepts and micro-cases. Oxford: Blackwell Publishing.

Barney, J. B., \& Hesterly, W. S. (2010). Strategic Management and competitive advantage: Concepts and Cases (3 ${ }^{\text {rd }}$ ed.). New Jersey, USA: Prentice Hall.

Besanko, D., Dranove, D., Shanley, M., Schaefer, S. (2010). Economics of strategy (5 ${ }^{\text {th }}$ ed.). New York: John Wiley \& Sons.

Capon, C. (2008). Understanding Strategic Management. Harlow: Pearson Education.

Carpenter, M. A., Sanders, W. G. (2009). Strategic management: A dynamic perspective concepts and cases (2nd ed.). New Jersey, USA: Pearson, Prentice Hall.

David, F. R. (2011). Strategic management: Concepts (13 ${ }^{\text {th }}$ ed.). New Jersey, USA: Pearson Education.

De Wit, B., \& Meyer, R. (2010a). Strategy process, content, context: An international perspective (4th ed.). Mason USA: South Western Cengage Learning.

De Wit, B., \& Meyer, R. (2010b). Strategy synthesis: Resolving strategy paradoxes to create competitive advantage ( $3^{\text {rd }}$ ed.). Andover, UK: Cengage Learning.

Dess, G. G., Lumpkin, G. T., Eisner, A. B., \& McNamara, G. (2010). Strategic management texts and cases (5 $5^{\text {th }}$ ed.). New York, USA: Mc-Graw-Hill Irwin.

Grant, R. M. (2010). Contemporary strategy analysis (7th ed.). West Sussex: Wiley \& Sons.

Hanson, D., Hitt, M. A., Ireland, R. D., \& Hoskisson, R. E. (2011). Strategic management: Competitiveness and globalisation (Asia-Pacific $4^{\text {th }}$ ed.). Melbourne: Cengage Learning Australia.

Harrison, J. S., \& St. John, C. H. (2010). Foundations in strategic management (5th ed.). Mason USA: South Western Cengage Learning.

Hill, C. W. L., \& Jones, G. R. (2010). Strategic management: An integrated approach (9 ${ }^{\text {th }}$ ed.). Mason, USA: South Western Cengage Learning.

Hill, C. W. L., \& Jones, G. R. (2012). Essentials of strategic management (3 ${ }^{\text {rd }}$ ed.). Mason USA: Southwestern Cengage Learning.

Hitt, M. A., Ireland, D. R., \& Hoskisson, R. E. (2011). Strategic management: Competitiveness and globalization: Concepts and cases ( $9^{\text {th }}$ ed.). Mason USA: South Western Cengage Learning.

Hubbard, G., \& Beamish, P. (2011). Strategic management: Thinking, analysis, action (4th ed.). Frenchs Forest NSW: Pearson Australia.

Johnson, G., Whittington, R., \& Scholes, K. (2011). Exploring strategy, (9th ed.). Harlow, Essex: Pearson Education.

Saloner, G., Shepard, A., \& Podolny, J. (2001). Strategic management. New York USA: J Wiley \& Sons.

Thompson, A. A., Peteraf, M. A., Gamble, J. E., \& Strickland, A. J. (2012). Creating \& executing strategy: The quest for competitive advantage, concepts \& cases (18 ${ }^{\text {th }}$ ed.). New York: Mc-Graw Hill/Irwin.

Thompson, J., \& Martin, F. (2010). Strategic management, awareness and change (6 $6^{\text {th }}$ ed.). Hampshire, UK: South Western Cengage Learning.

Viljoen, J., \& Dann,S. (2003). Strategic management (4th ed.). Frenchs Forest, NSW: Prentice Hall, Pearson Education Australia.

Wheelan, T. L., \& Hunger, D. J. (2010). Strategic management and business policy: Achieving sustainability (12 ${ }^{\text {th }}$ ed.). New Jersey, USA: Prentice Hall.

Witcher, B. J., \& Chau, S. (2010). Strategic management: Principles and practice (1 ${ }^{\text {st }}$ ed.). Mason USA: South Western Cengage Learning.

This splitting of the environment into external and internal is as De Wit and Meyer (2010a) highlight the "first dichotomy" (p. 11) managers' face. The "external environment influences firms as they seek strategic competitiveness" (Hitt et al., 2011: 36), however it is largely "beyond the direct control of a single organization" (David, 2011: 43). In contrast, the "internal environment [which] is subject to far more control" (Witcher \& Chau, 2010:122) and is the 
source of "organizational strengths and weaknesses" (Barney \& Hesterly, 2010: 8). Thus whereas the goal of external analysis is to "understand opportunities and threats" (Hill \& Jones, 2010: 39), internal analysis "focuses on resources and capabilities as internal sources of uniqueness that allow firms to beat the competition" (Carpenter \& Sanders, 2009: 23).

Finally, as an addendum, given the sustainable development context of this article it is worthwhile briefly considering the definitions of sustainable development offered by the texts. Only one textbook actually offers the Brundtland definition, while 15 texts do not define the term at all, and the remaining seven texts develop their own terms. Where texts have developed their own construct, invariably that construct is narrow in its focus and concerned with the so-called 'natural environment' and an organization's ability to "protect, mend and preserve" (David, 2011: 343) this environment. Further "a number of companies are developing environmentally friendly policies" (Hitt et al., 2011: 49) because of an increasing concern about the natural environment, albeit the natural environment, where it is and what it is, is not defined. Alternatively sustainability is "concerned with the relationship of a company to its environment and its use of natural resources, including land, water, air, plants, animals, minerals, fossil fuels and biodiversity" (Thompson et al., 2012: 316). Furthermore rather than sustainability's being concerned with the needs of generations present and future, the focus of sustainable development is "stakeholders" (Hubbard \& Beamish, 2011: 12), a more limited constituency, and their needs in the future.

\section{DISCUSSION}

Strategy textbooks have been described as suffering from a degree of isomorphism and being akin to recipe books (e.g., Spender, 1989; Whittington, 1993) that belie a promise that, through adherence to the recipe, the delights of a successful strategy will be realized (Spender, 1989; Whittington, 1993). The results of this analysis also reveal a degree of isomorphism particularly in how the environment is conceptualized.

As shown the environment is conceptualized with a lack of definitional exactitude; it consists of multiple categories and hinges on there being internal and external master sets. The external environment is separate and beyond direct control. It is also constricted to being a repository of opportunities and threats that need to be exploited or avoided, rather than, and to lean on simplistic examples, its being "where we all live" (WCED, 1987: xi) and something which is entwined with us (Ingold, 2011). Similarly, the internal environment is not somewhere individuals spend significant amounts of their life; rather it is a source of organizational strengths and weaknesses that need to be matched to the external opportunities and threats.

As Grant (2010) highlights, the emphasis of these books is not necessarily the realization of sustainable outcomes but rather the "identification of profit opportunities in the external environment of the firm" (Grant, 2010: 122). The texts present a relatively thin construct of the environment as being a dehumanized place that is a separable collection of categories in four domains: external threats, external opportunities, internal weaknesses, and internal strengths. Such a characterization undoubtedly constrains the ability of the strategist to move beyond this simple, dehumanized perception (Clegg et al., 2004). 
A constricted, separable construct of the environment is consistent with the requirement to allow analysis that enables the narrow aims of the texts. However the separating out of the environment into external and internal components partitioned by an organizational boundary releases a challenge that the constructs used and the analysis facilitated through those same constructs is what in turn "objectifies the environment to which...[individuals] then turn and respond" (Hatch, 2011: 55). Further that the notion of an organizational boundary is a central to the constructs of the environment developed in the textbooks, any move away from such a construct would be significant and difficult. This is because it has been argued that since Coase's (1937) article on the nature of firm organizational boundaries are the central concern of organizational theory and analysis (e.g., Dolfsma \& Dannreuther, 2003; Hernes, 2004). As such the idea of a boundary has served organizational analysis for decades, particularly as boundaries and their reproduction, it is argued, enable organisations to persist (e.g., Hernes, 2004). Consequently, while the boundary reinforces objectification and a dualism that limits the enabling of sustainable development, the deconstruction of such a dualism is a difficult challenge for textbooks that necessarily require an audience and because of such a requirement are potentially limited in their ability to challenge dominant thinking.

The constructs in the textbooks analyzed reinforce a fractured epistemology (Gladwin et al., 1995) that separates the organization from everything else, an aspect that in turn hinders the potential ability of corporate strategists who may use or have used such texts to realize sustainable outcomes. The relatively sclerotic construct of the environment offered by the textbooks is one where the environment is viewed as "something outside and completely unrelated to the observer, except in a very narrow utilitarian sense" (Purser et al., 1995: 1064). It is arguably an example of how our knowledge systems leave behind our reality, a reality of systemic interconnections in a borderless world (Shrivastava, 1995; King, 1995; Gladwin, 1995). A world that is an "intrinsically dynamic, interconnected web of relations in which there are no absolutely discrete entities and no absolute dividing lines" (Eckersley, 2003: 49). While the language in the textbooks could be dismissed as just language games; such a dismissal would compromise their value and in turn not acknowledge that language is "both descriptive and constitutive of reality" (Tsoukas, 1991: 568). Wherein language is a "cognitive technology that directly shapes our relations with the world, guiding how we think and act" (Morgan, 2012: 12; in support also see Cornelissen, 2002, 2004, 2005; Lakoff \& Johnson, 1980; Lakoff \& Turner, 1987; Tsoukas, 1991, 1993). Thus language guides our cognitive representations and, in turn, our actions through enactment theory (e.g., Hatch, 2011; Smircich \& Stubbart, 1985).

Notwithstanding the challenge of language, the relatively sclerotic view offered might be necessary given our continual desire for order out of chaos. To explain, "given bounded rationality and environmental complexity, sense making tends to crystallize into cognitive frames that reduce ambiguity and facilitate decision making" (Santos \& Eisenhardt, 2005: 500). Thus it has been argued that humans "tend toward static, isolated, one factor at a time analysis rather than dynamic whole systems appraisal” (Gladwin et al., 1997: 241). Consequently a narrow, compartmentalized understanding of the environment, as offered by textbooks, is perhaps a necessary requirement in order to facilitate our own sensemaking. Particularly as "purposeful classifications of objects, people and events are ... [it can be argued] an indispensable requirement for thinking about competition or strategy" (Bourgeois, 1980: 333). 
Order seeking and bounded rationality aside, it can also be argued that the limitations of the English language do not enable a move past dualistic implications. To explain, language allows us to detach ourselves and create symbolic distance (e.g., Deleuze \& Guattari, 2007; Newton, 2007). Further the subject-verb structure of the English language can reinforce separation and reification. For example, Ingold (2011) outlines how an individual might typically say "the wind blows" (Ingold, 2011: 17). The structure of the phrase reinforcing notions of there being a wind (subject) that is separate to the action of blowing. As if the blowing is a separate act upon the body that is the wind. Thus language structure and its semiotic underpinnings are implying compartmentalization and separation. In this way language perpetuates a kind of fracture between subject and action (wind and blowing). To counter the fracturing, Ingold (2011) argues, perhaps self-evidently, that the "wind is its blowing" (Ingold, 2011: 17). The wind is the result of the blowing, and thus there is no separation between subject and action. Indeed, the wind would not exist without the blowing. The wind is therefore the process, or the action. Similarly an organization and its environment are co-constitutive of each other, not independently given entities. However co-constitution may not be an actionable construct given the bounded rationality of humans.

Nearly 30 years ago Smircich and Stubbart (1985) commented, “[A]ccording to most strategic management literature, an organization ... exists within an independently given environment" (Smircich \& Stubbart, 1985: 724). This research indicates that little seems to have moved on since then. Perhaps the lack of movement is because of cognitive limitations as opposed to, for example, ideological hegemony. However the fact that the textbooks analyzed fail to, in the main, even acknowledge sustainability or sustainable development in their indexes perhaps belies the filtering of sustainability into the consciousness of organizational theorists and thus arguments of ideological hegemony cannot stand.

Although Smircich and Stubbart's (1985) comments of nearly 30 years ago outlined how organizations operate in the world, not on it, it can be argued that there is nothing particularly novel or new about highlighting the limitations of the environmental construct offered in the bestselling strategic management textbooks of 26 years later. However since the 1985 publication of Smircich and Stubbart's article, sustainable development has become popularized, and the challenge of conventional organizational theories and their perpetuation of a dualism that does not enable sustainable outcomes has been discussed. Yet given all this discussion, textbooks do not seem to have moved forward in their constructs to enable corporate strategists, key actors, to realize sustainable outcomes. Further we are still in the foothills of a sustainability management theory, and the reflection of the near obvious regarding our mutual embedding and inseparability from all that surrounds us (Starik \& Kanahsiro, 2013).

"The modern mind is still haunted by the belief that the only meaningful concepts are those capable of mathematical elucidation...This rationalism supports the doctrine that facts are separate from values... and that truth is a function of objective reality" (Gladwin et al., 1997: 248)

\section{REFERENCES}

Apple, M., \& Christian-Smith, L. 1991. The politics of the textbook. In M. Apple \& L. Christian-Smith (Eds.), The Politics of the Textbook, pp. 1-22, London: Routledge. 
Banerjee, S. B. 2003. Who sustains whose development? Sustainable development and the Reinvention of Nature. Organization Studies, 24: 143-180.

Barney, J. B., \& Hesterly, W. S. 2010. Strategic management and competitive advantage: Concepts and cases (3rd ed). New Jersey, USA: Prentice Hall.

Blewitt, J. 2008. Understanding sustainable development. London: Earthscan.

Boisot, M. \& McKelvey, B. 2010. Integrating modernist and postmodernist perspectives on organizations: A complexity science bridge. Academy of Management Review, 35(3), 415-433.

Bourgeois, L. J. 1980. Strategy and environment: A conceptual integration. Academy of Management Review, 5(1), 25-39.

Bouvier P. B, 1984. The Emperor's new clothes: Management texts, management education and misinformation. Academy of Management Proceedings, August, pp.116-120.

Byrch, C., Kearins, K., Milne, M., \& Morgan, R. 2007. Sustainable "what”? A cognitive approach to understanding sustainable development. Qualitative Research in Accounting and Management, 4(1), 26-52.

Cameron, K., Ireland, .R. D., Lussier, R. N., New, J. R., \& Robbins, S. P. 2003. Management textbooks as propaganda. Journal of Management Education, 27(6), 711-729.

Capon, C. 2008. Understanding strategic management. Harlow: Pearson Education.

Carpenter, M. A., \& Sanders, W. G. 2009. Strategic management: A dynamic perspective concepts and cases (2nd ed.). New Jersey, USA: Pearson, Prentice Hall.

Carson, R. 1962. Silent Spring. USA: Houghton Mifflin.

Castree, N. 2002. False antitheses? Marxism, nature and actor-networks. Antipode, 34(1), 111-116.

Clegg, S., Carter, C., \& Kornberger, M. 2004. Get up, I feel like being a strategy machine. European Management Review, $1,21-28$.

Coase, R. 1937. The nature of the firm. Economica, 4(4), 386-405.

Cornelissen, J. P. 2002. On the 'Organizational identity' Metaphor. British Journal of Management, 13, $259-268$.

Cornelissen, J. P. 2004. What are we playing at? Theatre, organization, and the use of metaphor. Organization Studies, 25(5), 705-726.

Cornelissen, J. P. 2005. Beyond compare: Metaphor in organization theory. Academy of Management Review, 30(4), 751764.

Crawford, K. 2003. The role and purpose of textbooks. International Journal of Historical Learning, Teaching and Research, $3(2), 5-11$.

Cronon, W. 1992. A place for stories: Nature, history and narrative. The Journal of American History, 78(4), $1347-1376$.

Cummings, S., \& Bridgman, T. 2011. The relevant past: Why the history of management should be critical for our future. Academy of Management Learning \& Education, 10(1), 77-93.

David, F. R. 2011. Strategic management: Concepts (13th ed.). New Jersey, USA: Pearson Education.

Deleuze, G., \& Guattari, F. 2007. A thousand plateaus. London: Continuum.

Dess, G. G., Lumpkin, G. T., Eisner, A. B., \& McNamara, G. 2010. Strategic management texts and cases (5th ed.). New York, USA: Mc-Graw-Hill Irwin.

De Wit, B., \& Meyer, R. 2010. Strategy process, content, context: An international perspective (4th ed.). Mason, USA: South Western Cengage Learning.

Dolfsma, W., \& Dannreuther, C. 2003. Subjects and boundaries: Contesting social capital-based policies. Journal of Economic Issues, 37, 405-413.

Eckersley, R. 2003. Environmentalism and political theory: Towards an ecocentric approach (reprint of 1992 edition). London: Routledge.

Egri, C. P., \& Pinfield, L. T. 1999. Organizations and the biosphere: Ecologies and environments. In S.R. Clegg, C. Hardy \& W.R. Nord (Eds.), Managing Organizations (pp. 209-233). London: Sage.

Enz, C. A. 1986. Strategy Textbooks: A case of consistently inconsistent evaluations. Academy of Management Review, 11(1), 226-237.

Ferguson, J., Collison, D. J., Power, D. M., \& Stevenson, L. A. 2006. Accounting textbooks: exploring the production of a cultural and political artefact. Accounting Education: an international journal, 15(3), 1-18.

Fiol, C. M. 1989. A Semiotic analysis of corporate language: Organizational Boundaries and Joint Venturing. Administrative Science Quarterly, (34), 277-303.

Gilbert, D. R. 2003. Propaganda, trusteeship, and artifact. Journal of Management Education, 27(6), 730-739.

Gladwin, T. N., Kennelly, J.J., \& Krause, T. S. 1995. Shifting paradigms for sustainable development: Implications for management theory and research. Academy of Management Review, 20(4), 874-907.

Gladwin, T. N., Newburry, W. E., \& Reiskin, E. D. 1997. Why is the northern elite mind biased against community, the environment and a sustainable future?. In M.H. Bazerman et al. (Eds.), Environment, Ethics and Behavior: The Psychology of Environmental Valuation and Degradation. San Francisco: The New Lexington Press. 
Grant, R. M. 2010. Contemporary strategy analysis, (7th ed.). West Sussex: Wiley \& Sons.

Gray, R., Bebbington, J., \& Walters, D. 1993. Accounting for the Environment. London: Paul Chapman Publishing.

Guattari, F. 1989. The three ecologies. New formations, 8(Summer), 131-147.

Hackley, C. 2003. We are all customers now: Rhetorical strategy and ideological control in marketing and management texts. Journal of Management Studies, 40(5), 325-1352.

Hanson, D., Hitt, M. A., Ireland, R. D., \& Hoskisson, R. E. 2011. Strategic management: Competitiveness and globalisation (Asia-Pacific 4th ed.). Melbourne, Australia: Cengage Learning.

Harrison, J. S., \& St. John, C. H. 2010. Foundations in strategic management (5th ed.). Mason, USA: South Western Cengage Learning.

Hatch, M. J. 2011. Organizations: A very short introduction. Oxford: Oxford University Press.

Hernes, T. 2004. Studying composite boundaries: A framework of analysis. Human Relations, 57, 9-29.

Hill, C. W. L., \& Jones, G. R. 2012. Essentials of strategic management (3rd ed.). Mason, USA: Southwestern Cengage Learning.

Hitt, M. A., Ireland, R. D., \& Hoskisson, R. E. 2011. Strategic management: Competitiveness and globalization: Concepts and cases (9th ed.). Mason, USA: South Western Cengage Learning.

Hopwood, B., Mellor, M., \& O’Brien, G. 2005. Sustainable development: Mapping different approaches. Sustainable Development 13(1), 38-52.

Hubbard, G., \& Beamish, P. 2011. Strategic management: Thinking, analysis, action (4th ed.). Frenchs Forest, NSW: Pearson Australia.

Ingold, T. 2011. Being alive: Essays on movement, knowledge and description. Abingdon, UK: Routledge.

Issitt, J. 2004. Reflections on the study of textbooks. History of Education, 33(6), 683-696.

Johnson, G., Whittington, R., \& Scholes, K. 2011. Exploring Strategy (9th ed.). Harlow, Essex: Pearson Education.

Kates, R. W., Parris, T. M., \& Leisorwitz , A. A. 2005. What is sustainable development. Environment, 47 (3): 8-21.

Katz, J., \& Gardner, W.B. 1988. Properties of emerging organizations. The Academy of Management Review, 13(3), 429441.

King, A. 1995. Avoiding ecological surprise: Lessons from long standing communities. Academy of Management Review, 20(4), 961-985.

Krippendorff, K. 2004. Content analysis: An introduction to its methodology (2nd ed.). California: Sage.

Lakoff, G., 2010. Why it Matters How We Frame the Environment. Environmental Communication. 4(1), $70-81$.

Lakoff, G., \& Johnson, M. 1980. Metaphors we live by. Chicago: University of Chicago Press.

Lakoff, G., \& Turner, M. 1987. More than cool reason: A field guide to poetic metaphor. Chicago: University of Chicago Press.

Latour, B. 1999a. On recalling ANT. In J. Law \& J. Hassard (eds.), Actor Network Theory and After. Oxford: Blackwell.

Latour, B. 1999b. Pandora's hope essays on the reality of science studies. London: Harvard University Press.

Lele, S. 1991. Sustainable development: A critical review. World Development 19(6): 607-621.

March, J. G., \& Simon, H. A. 1958. Organizations. New York: Wiley.

McAuley, J., Duberle, J., \& Johnson, P. 2007. Organization theory: Challenges and perspectives. London: FT Prentice Hall.

Mebratu, D. 1998. Sustainability and sustainable development: Historical and conceptual Review. Environmental Impact Assessment Review, 18(6), 493-520.

Mir, A. 2003. The hegemonic discourse of management texts. Journal of Management Education, 27(6), 734-738.

Morgan, G. 2012. Reflections on images of organization and its implications for organization and environment. Organization \& Environment, 4(24), 1-20.

Newton, T. 2002. Creating new ecological order? Elias and actor-network theory. Academy of Management Review, 27(4), 523-540.

Newton, T. 2007. Nature and sociology. Abingdon, Oxon: Routeledge.

Pingel, F. 1999. UNESCO guidebook on textbook research and textbook revision. Hannover: Verlag Hahnsche Buchhandlung.

Purser, R. E., Park, C., \& Montuori, A. 1995. Limits to anthropocentrism: Toward an ecocentric organization paradigm?. Academy of Management Review, 20(4), 1053-1089.

Redclift, M. 2005. Sustainable development (1987-2005): An oxymoron comes of age. Sustainable Development, 13, $212-$ 227.

Robson, C. 2002. Real world research (2nd ed.). Oxford: Blackwell Publishing.

Ross, J. E., \& Murdick, R. G. 1977. What are the principles of management?. Academy of Management Review, 2(1), 436146.

Santos, F. M., \& Eisenhardt, K. M. 1985. Organizational boundaries and theories of organization. Organization Science, 16(5), 491-508. 
Sarasvathy, S. D. 2001. Causation and effectuation: Toward a theoretical shift from economic inevitability to entrepreneurial contingency. Academy of Management Review, 26(2), 243-263.

Sarasvathy, S. D. 2004. Making it happen: Beyond theories of the firm to theories of firm design. Entrepreneurship Theory and Practice, Winter, 519-531.

Shrivastava, P., \& Hart, G. 1994. Greening organizations - 2000. International Journal of Public Administration, 17(3-4), 607-635.

Shrivastava, P. 1995. The role of corporations in achieving ecological sustainability. Academy of Management Review, 20(4), 936-960.

Simon, H. A. 1947. Administrative behavior: A study of decision-making processes in administrative organizations. New York: Simon \& Schuster.

Steer, A., \& Wade-Gery, W. 1993. Sustainable development: Theory and practice for a sustainable future. Sustainable Development, 1(3), 23-35.

Smircich, L., \& Stubbart, C. 1985. Strategic management in an enacted world. Academy of Management Review, 10(4), 724-736.

Starik, M., Kanashiro, P. 2013. Toward a Theory of Sustainability Management: Uncovering and Integrating the Nearly Obvious. Organization \& Environment, 26(1): 7-30.

Spender, J. C. 1989. Industry recipes: The nature and sources of managerial judgement. Oxford: Basil Blackwell.

Thompson, J., \& Martin, F. 2010. Strategic management, awareness and change (6th ed.). Hampshire, UK: South Western Cengage Learning.

Thompson, A. A., Peteraf, M.A., Gamble, J. E., \& Strickland, A. J. 2012. Creating \& executing strategy: The quest for competitive advantage: Concepts \& Cases (18th ed.). New York: Mc-Graw Hill/Irwin.

Tsoukas, H. 1991. The Missing link: A transformational view of metaphors in organizational science. Academy of Management Review, 16(3), 566-585.

Tsoukas, H. 1993. Analogical reasoning and knowledge generation in organization theory. Organization Studies, 14, 323-346.

United Nations Secretary - General's High Level Panel on Global Sustainability 2012. Resilient people, resilient planet: $A$ future worth choosing. New York: United Nations.

Viljoen, J., \& Dann, S. 2003. Strategic management (4th ed.). Frenchs Forest, NSW: Prentice Hall, Pearson Education Australia.

Wheelan, T. L., \& Hunger, D. J. 2010. Strategic management and business policy: Achieving sustainability (12th ed.). New Jersey, USA: Prentice Hall.

Whittington, R. 1993. What is strategy - and does it matter?. London: Routledge.

Witcher, B. J., \& Chau, S. 2010. Strategic management: Principles and practice (1st ed.). Mason USA: South Western Cengage Learning.

World Commission on Environment and Development 1987. Our common future. Oxford: Oxford University Press. Yates, J. J. 2012. Abundance on trial: The cultural significance of sustainability. The Hedgehog Review, Summer, 8-25. 